\title{
FAKTOR-FAKTOR YANG MEMPENGARUHI PENERIMAAN OPINI AUDIT GOING CONCERN
}

\author{
Andreas Vernando \\ Arif Sapta Yuniarto
}

\begin{abstract}
Auditor in doing a audit is responsible to evaluate whether auditee gets problem in maintainig its existence. One of its indication is auditee gets the financial distress. Therefore, if doubting a capable auditee in maintainig its existence, Auditor commonly brings out going concern audit opinion for giving signalement to investor so that investor does not make the mistake in interpretating the economic decision. The researchs with topics going-concern audit opinion have been comprehensive enough. this is seen of many variables gone into researchs model. However, researchs with topics going-concern audit opinion must be continously renewed. This is caused economy condition that is always dinamic having to research continously. This research purposed to obtain the empirical evidence of factors influencing acceptance going-concern audit opinion. This research focussed for researching manufacture sector which was listed at Indonesian stock exchange from periods 2009 until 2012 used as research sample. the result of purposive sampling method was obtained as many as 39 manufacture companies which fill up sample criterion and the tests of hypotesis use logistic regression analysis. The results of hypotesis test showed that tenure influenced acceptance of going-concern audit opinion..
\end{abstract}

Keywords: auditor quality, tenure, disclosure, company growth, prior audit opinion, liquidity ratio, activity ratio, solvability ratio, profitability ratio and going-concern audit opinion.

\section{PENDAHULUAN}

Auditor mempunyai peranan yang sangat penting dalam menjembatani konflik kepentingan antara investor dan manajemen. Hal ini dikarenakan investor dalam hal ini pemilik perusahaan tidak cukup banyak mempunyai informasi mengenai kondisi keuangan perusahaan, sedangkan manajemen yang disewa untuk mengelola perusahaan memiliki cukup banyak informasi mengenai kondisi keuangan perusahaan.

Terkait dengan perikatan suatu audit, biasanya entitas diasumsikan merupakan perusahaan yang berkelanjutan (going concern) yang akan terus ada. Meskipun demikian, auditor mempunyai tanggung jawab untuk mengevaluasi entitas tersebut mempunyai kemampuan untuk terus melanjutkan usaha selama 
perioda waktu yang layak yaitu tidak melebihi satu tahun sesudah tanggal laporan keuangan yang telah diaudit (Boynton et al., 2003: 373). Apabila auditor mempunyai keraguan yang substansial tentang kemampuan perusahaan untuk mempertahankan kelangsungan usahanya tidak lebih dari satu tahun kedepan sejak tanggal laporan keuangan yang telah diaudit, maka auditor harus mengkomunikasikan hal ini melalui media laporan keuangan kepada investor dan pengguna laporan keuangan lain yang sebelumnya sudah dievaluasi terlebih dahulu oleh auditor tentang rencana manajemen untuk mengatasi masalah kelangsungan usahanya (SPAP, 2001). Auditor ketika memberikan opini audit going concern kepada auditee mempertaruhkan integritasnya, karena auditor berpendapat bahwa terdapat salah satu indikasi perusahaan tidak dapat mempertahankan kelangsungan usahanya dan sudah dapat dipastikan manajemen tidak menginginkan kabar buruk tersebut.

Menurut Ross et al. (2002) dikutip dalam Januarti dan Firianasari (2008) menyatakan bahwa indikasi kebangkrutan dapat dilihat dari apakah perusahaan mengalami kesulitan keuangan, yaitu suatu kondisi arus kas operasi perusahaan tidak mencukupi untuk memenuhi kewajiban lancarnya. Kesulitan kondisi keuangan akan mempengaruhi rasio keuangan yang buruk yang pada akhirnya mengarah kepada kebangkrutan dan kelangsungan usahanya (going concern) akan diragukan. Kondisi keuangan perusahaan dapat dilihat dengan menggunakan rasiorasio keuangan, antara lain; rasio likuiditas, rasio aktivitas, rasio solvabilitas, rasio profitabilitas.

Penelitian ini merupakan pengembangan dari penelitian yang dilakukan oleh Junaidi dan Hartono (2010). Objek penelitian tersebut yaitu semua perusahaan yang listing di BEI. Sementara penelitian ini diperluas yang mencakup variabel non keuangan dan rasio keuangan. Penambahan variabel untuk rasio pertumbuhan perusahaan dan rasio aktivitas diperoleh dari penelitian Prayitno (2010), dan opini audit tahun sebelumnya, rasio likuiditas, rasio solvabilitas dan rasio profitabilitas diperoleh dari penelitian Susanto (2009). Objek dalam penelitian ini yaitu semua perusahaan manufaktur yang terdaftar di BEI, sehingga peneliti ingin mendapatkan hasil empiris terhadap penelitian mengenai faktor-faktor yang mempengaruhi 
penerimaan opini audit going concern.

\section{TINJAUAN PUSTAKA}

\section{Opini Audit Going Concern}

Perusahaan dalam menghadapi ketidakpastian kelangsungan usahanya, akuntansi menganut konsep going concern atau usaha berlanjut atas dasar penalaran bahwa harapan yang umum dalam mendirikan perusahaan adalah untuk berlangsung terus dan bukan untuk dilikuidasi (Suwardjono, 2005: 222). Perusahaan dalam membuat laporan keuangan harus disusun berdasarkan asumsi kelangsungan usaha (going concern). Apabila laporan keuangan tidak disusun berdasarkan asumsi kelangsungan usaha, maka kenyataan tersebut harus diungkapkan bersama dengan dasar lain yang digunakan dalam penyusunan laporan keuangan, serta alasan mengapa asumsi kelangsungan usaha tidak dapat digunakan (PSAK, 2007).

Auditor dalam melaksanakan audit atas laporan keuangan, auditor umumnya bertugas menyatakan opini tentang kewajaran, dalam semua hal yang material, posisi keuangan, hasil usaha, perubahan ekuitas, dan arus kas sesuai dengan prinsip akuntansi yang berlaku di Indonesia. Laporan auditor merupakan sarana bagi auditor untuk menyatakan apabila keadaan mengharuskan, untuk menyatakan tidak memberikan opini, terdapat keadaan-keadaan yang dapat mengharuskan auditor menyimpang dari laporan auditor bentuk baku (SPAP, 2001). Salah satu laporan auditor yang menyimpang dari bentuk baku adalah laporan dengan opini audit going concern. Penerimaan opini audit going concern merupakan opini audit yang dikeluarkan oleh auditor kepada auditee dikarenakan auditor berkesimpulan bahwa auditee mengalami ketidakpastian dalam mempertahankan usahanya dengan perioda waktu yang pantas, tidak lebih dari satu tahun sejak laporan keuangan yang sedang diaudit.

\section{PENGEMBANGAN HIPOTESIS}

\section{Kualitas Auditor}

Menurut Margereta (2005) dikutip dalam Muttaqin (2012) kualitas auditor merupakan citra kantor akuntan big four yang memiliki kualitas yang lebih tinggi 
dalam pelatihan dan pengakuan internasional, sehingga akan mempertinggi skala kantor akuntan tersebut dibandingkan dengan kantor akuntan non big four. Mutchler et al. (1997) dalam Muttaqin (2012) menyatakan bahwa KAP besar akan berusaha untuk menjaga nama dan menghindari tindakan yang menggangu nama besar mereka. Oleh sebab itu, KAP besar akan lebih berani memberikan opini audit going concern kepada auditee, jika memang ditemukan adanya masalah pada perusahaan yang diaudit.

Hasil penelitian yang dilakukan oleh Junaidi dan Hartono (2010) serta Prayitno (2010) menyatakan bahwa kualitas auditor berpengaruh terhadap penerimaan opini audit going concern yang dikeluarkan oleh auditor. Akan tetapi, hasil penelitian tersebut bertolakbelakang dengan hasil penelitian Susanto (2009) menyatakan sebaliknya. Oleh karena itu, hipotesis yang diajukan dalam penelitian ini adalah:

$\mathrm{H}_{1}$ : Kualitas auditor berpengaruh terhadap penerimaan opini audit going concern.

\section{Tenure}

Menurut Dewayanto (2011) tenure merupakan jumlah rentang waktu antara KAP yang melakukan suatu perikatan audit dengan auditee yang sama. Ketika terdapat KAP melakukan suatu perikatan audit secara terus-menerus terhadap auditee. Hal ini akan menyebabkan auditor kehilangan independensinya, sehingga kemungkinan auditor untuk memberikan opini going concern kepada auditee akan sulit. Oleh sebab itu, BAPEPAM menerbitkan Keputusan Ketua Badan Pengawas Pasar Modal dan Lembaga Keuangan Nomor: KEP-310/BL/2008 yang terdapat klausa yang membatasi suatu perikatan audit untuk KAP selama enam tahun berturut-turut dan auditor selama tiga tahun berturut-turut.

Hasil dari penelitian yang dilakukan oleh Junaidi dan Hartono (2010) serta Muttaqin (2012) menunjukkan bahwa tenure berpengaruh terhadap penerimaan opini audit going concern. Akan tetapi, hasil tersebut bertolakbelakang dengan hasil penelitian Sari (2012) menyatakan sebaliknya. Oleh karena itu, hipotesis yang diajukan selanjutnya adalah:

$\mathrm{H}_{2}$ : Tenure berpengaruh terhadap penerimaan opini audit going concern. 


\section{Disclosure}

Menurut Wolk et al. (2001) dikutip dalam Suwardjono (2005: 579) menginterpretasikan disclosure secara luas yaitu pengungkapan yang berhubungan dengan informasi, baik itu dalam laporan keuangan dan juga informasi tambahan yang mencakup antara lain; catatan kaki, peristiwa setelah laporan keuangan, diskusi dan analisis manajemen mengenai kegiatan operasi untuk di tahun yang akan datang, peramalan mengenai kegiatan operasi dan keuangan, dan tambahan laporan keuangan yang meliputi pengungkapan yang terdiri atas beberapa bagian dan perluasan yang melebihi biaya historis. Disclosure dalam laporan keuangan merupakan informasi yang sangat penting bagi auditor. Disclosure yang memadai atas informasi keuangan perusahaan tersebut menjadi salah satu dasar auditor dalam memberikan opininya atas kewajaran laporan keuangan perusahaan (Junaidi dan Hartono, 2010).

Hasil penelitian yang dilakukan oleh Sari (2012) menyatakan bahwa disclosure berpengaruh terhadap penerimaan opini audit going concern. Hasil ini sejalan dengan hasil penelitian Junaidi dan Hartono (2010). Oleh karena itu, hipotesis yang diajukan selanjutnya adalah:

$\mathrm{H}_{3}$ : Disclosure berpengaruh terhadap penerimaan opini audit going concern.

\section{Pertumbuhan Perusahaan}

Menurut FASB (2008) yang dituangkan dalam SFAC No. 6 paragraf 70 mendefinisikan laba yaitu perubahan dalam ekuitas perusahaan bisnis selama suatu perioda dari transaksi maupun peristiwa lainnya dan keadaan dari sumber nonpemilik. Hal tersebut mencakup semua perubahan dalam ekuitas selama suatu perioda kecuali sumber yang dihasilkan dari investasi oleh pemilik dan distribusi kepada pemilik.

Menurut Santosa dan Wedari (2007) laba yang mengalami peningkatan merupakan kabar baik bagi investor, sedangkan laba yang mengalami penurunan merupakan kabar buruk bagi investor. Perusahaan yang mempunyai pertumbuhan laba yang tinggi cenderung memiliki laporan sewajarnya, sehingga potensi untuk mendapatkan opini non-going concern akan lebih besar. Hasil Penelitian yang 
dilakukan oleh Prayitno (2010) pertumbuhan perusahaan yang diproksi menggunakan pertumbuhan laba berpengaruh terhadap penerimaan opini audit going concern. Oleh karena itu, hipotesis yang diajukan selanjutnya adalah:

$\mathrm{H}_{4}$ : Pertumbuhan perusahaan berpengaruh terhadap penerimaan opini audit going concern.

\section{Opini Audit Tahun Sebelumnya}

Opini audit tahun sebelumnya adalah tipe opini audit yang telah diterima perusahaan pada tahun sebelumnya (Prayitno, 2010). Auditee yang menerima opini audit going concern pada tahun sebelumnya akan dianggap memiliki masalah kelangsungan hidupnya. Dengan demikian, semakin besar kemungkinan bagi auditor untuk mengeluarkan opini audit going concern pada tahun berjalan (Dewayanto, 2011). Hal ini dapat diterima karena auditor akan lebih konsen terhadap masalah yang ditahun sebelumnya terdapat masalah yang krusial dan berpeluang masalah tersebut berlanjut pada audit tahun berjalan sehingga manajemen harus menunjukkan peningkatan yang sangat signifikan terhadap kinerja keuangan.

Hasil penelitian yang dilakukan oleh Susanto (2009), serta Muttaqin (2012) yang menyatakan bahwa opini audit tahun sebelumnya berpengaruh terhadap penerimaan opini audit going concern. Oleh karena itu, hipotesis yang diajukan selanjutnya adalah:

$\mathrm{H}_{5}$ : Opini audit tahun sebelumnya berpengaruh terhadap penerimaan opini audit going concern.

\section{Rasio Likuiditas}

Rasio likuiditas mengukur kemampuan jangka pendek perusahaan dengan melihat aktiva lancar perusahaan relatif terhadap utang lancarnya (Hanafi dan Halim, 2003: 79). Apabila likuiditas yang diproksi dengan rasio lancar kurang dari 2, hal ini dapat dikatakan kurang baik sehingga kreditor cenderung tidak akan memberikan bantuan kepada perusahaan, karena kreditor khawatir akan kemampuan perusahaan dalam hal membayar kewajiban-kewajiban jangka pendeknya. Dengan demikian, perusahaan mengalami kesulitan dalam hal 
pendanaan yang berimplikasi terhadap dikeluarkannya opini audit going concern.

Hasil penelitian yang dilakukan oleh Sari (2012) menyatakan bahwa rasio likuditas dengan proksi rasio lancar berpengaruh terhadap penerimaan opini audit going concern. Dengan demikian, hipotesis yang diajukan selanjutnya adalah:

$\mathrm{H}_{6}$ : Rasio likuiditas berpengaruh terhadap penerimaan opini audit going concern.

\section{Rasio Aktivitas}

Rasio aktivitas mengukur sejauh mana efektivitas penggunaan aset dengan melihat tingkat aktivitas aset dan rasio aktivitas melihat pada aktiva tersebut pada tingkat kegiatan tertentu (Hanafi dan Halim, 2003: 82). Menurut Weston dan Copeland (1992) dalam Januarti dan Fitrianasari (2008) menyatakan bahwa harus ada keseimbangan antara penjualan dengan berbagai unsur aktiva, yaitu persediaan, piutang, aktiva tetap dan aktiva lain, rasio aktivitas yang tinggi mencerminkan bahwa perusahaan benar-benar dapat melakukan kegiatan operasi utamanya dan dengan demikian diharapkan kelangsungan usahannya dapat dipertahankan.

Hasil penelitian yang dilakukan oleh Prayitno (2010) yang menyatakan bahwa rasio aktivitas yang diproksi menggunakan total asset turnover berpengaruh terhadap penerimaan opini audit going concern. Dengan demikian, hipotesis yang diajukan selanjutnya adalah:

$\mathrm{H}_{7}$ : Rasio aktivitas berpengaruh terhadap penerimaan opini audit going concern.

\section{Rasio Solvabilitas}

Rasio solvabilitas mengukur sejauh mana kemampuan perusahaan memenuhi kewajiban jangka panjangnya. Perusahaan yang tidak solvabel adalah perusahaan yang total utangnya lebih besar dibandingkan total asetnya (Hanafi dan Halim, 2003: 83). Rasio solvabilitas yang tinggi dapat berdampak buruk bagi kondisi keuangan perusahaan. Semakin tinggi rasio solvabilitas, semakin menunjukkan kinerja keuangan perusahaan yang buruk dan dapat menimbulkan ketidakpastian mengenai kelangsungan hidup perusahaan, hal ini menyebabkan perusahaan lebih berpeluang mendapatkan opini audit going concern (Noverio, 2011). Hasil penelitian yang dilakukan oleh Susanto (2009) menunjukkan bahwa rasio solvabilitas dengan proksi debt to total asset berpengaruh terhadap 
penerimaan opini audit going concern. Oleh karena itu, hipotesis yang diajukan selanjutnya adalah:

$\mathrm{H}_{8}$ : Rasio solvabilitas berpengaruh terhadap penerimaan opini audit going concern.

\section{Rasio Profitabilitas}

Rasio profitabilitas mengukur kemampuan perusahaan menghasilkan keuntungan pada tingkat penjualan, aset, dan modal saham tertentu. Penelitian ini rasio profitabilitas diproksi menggunakan return on asset (Hanafi dan Halim, 2003: 85). Ketika perusahaan mempunyai profitabilitas yang tinggi diharapkan dapat memperoleh laba yang tinggi, sehingga kemungkinan kecil bagi perusahaan untuk memperoleh opini audit going concern (Januarti dan Fitrianasari, 2008).

Hasil penelitian yang dilakukan oleh Susanto (2009) menyatakan bahwa profitabilitas diproksi menggunakan return on asset berpengaruh terhadap penerimaan opini going concern. Hasil ini sejalan dengan hasil penelitian Muttaqin (2012). Oleh karena itu, hipotesis yang diajukan selanjutnya adalah:

$\mathrm{H}_{9}$ : Rasio profitabilitas berpengaruh terhadap penerimaan opini audit going concern.

\section{METODA PENELITIAN}

\section{Sampel}

Sampel penelitian ini adalah perusahaan manufaktur yang terdaftar di BEI. Metoda pemilihan sampel dalam penelitian ini dilakukan dengan menggunakan purposive sampling method, yaitu metoda pengambilan sampel berdasarkan kriteria-kriteria tertentu. Adapun kriteria penentuan sampel adalah sebagai berikut:

1. Perusahaan manufaktur yang terdaftar di BEI pada tahun 2008-2012 dan mengeluarkan laporan tahunan dan laporan keuangan secara rutin pada tahun 2008-2012.

2. Terdapat laporan auditor atas laporan keuangan perusahaan selama tahun 2008-2012.

3. Terdapat catatan atas laporan keuangan perusahaan, serta tersedia data-data yang dimiliki perusahaan untuk di analisis pada perioda penelitian. 


\section{Definisi Operasional dan Pengukuran Variabel}

\section{Penerimaan Opini Audit Going Concern (Y)}

Penerimaan opini audit going concern merupakan opini audit yang dikeluarkan oleh auditor kepada auditee dikarenakan auditor berkesimpulan bahwa auditee mengalami ketidakpastian dalam mempertahankan usahanya (SPAP, 2001). Variabel dummy digunakan untuk mengukur variabel ini, jika opini audit going concern diberi kode 1, sedangkan opini non going concern diberi kode 0 . Pengukuran seperti ini pernah digunakan oleh Januarti dan Fitrianasari (2008).

\section{Kualitas Auditor (X1)}

Variabel dalam penelitian ini diukur dengan menggunakan variabel dummy. Peneliti memberikan kode 1 untuk perusahaan yang menggunakan jasa KAP big four, sedangkan kode 0 untuk perusahaan yang menggunakan jasa KAP non big four. Variabel ini pernah digunakan dalam penelitian Junaidi dan Hartono (2010). Kantor akuntan publik di Indonesia yang berafiliasi dengan the big four adalah:

a. Ernst \& Young berafiliasi dengan KAP Purwantono, Suherman dan Surja.

b. Deloitte Touche Tohmatsu berafiliasi dengan KAP Osman Bing Satrio.

c. KPMG berafiliasi dengan KAP Sidharta dan Widjaja.

d. Price Waterhouse Coopers berafiliasi dengan KAP Tanudiredja, Wibisana dan Rekan.

\section{Tenure (X2)}

Tenure diukur menggunakan skala interval sesuai dengan lama hubungan KAP dengan perusahaan. Pengukuran seperti ini pernah dilakukan dalam penelitian Junaidi dan Hartono (2010). Penelitian ini melakukan pengamatan selama empat tahun dari tahun 2009 sampai dengan 2012. Berdasar Keputusan Menteri Keuangan Nomor 17/PMK.01/2008 tentang Jasa Akuntan Publik dan Peraturan Ketua BAPEPAM No KEP-310/B1/2008 tentang Jasa Akuntan Publik yang mengatur tentang pemberian jasa audit umum atas laporan keuangan dari suatu entitas yang dilakukan oleh KAP paling lama enam tahun buku berturut-turut, dan oleh seorang akuntan publik paling lama tiga tahun buku berturut-turut. 


\section{Disclosure (X3)}

Disclosure merupakan landasan untuk terciptanya transparansi dan akuntabilitas karena sangat pentingnya pengungkapan tersebut. Pengukuran disclosure dilakukan dengan menggunakan indeks, yaitu membandingkan jumlah pengungkapan yang dilakukan oleh perusahaan dengan pengungkapan yang diwajibkan dalam peraturan BAPEPAM KEP-134/BL/2006 Peraturan Nomor X.K.6. Pengukuran dengan menggunakan indeks pernah digunakan dalam penelitian Junaidi dan Hartono (2010).

\section{Pertumbuhan Perusahaan (X4)}

Rasio pertumbuhan laba digunakan untuk mengukur kemampuan yang berkaitan dengan pertumbuhan perusahaan. Rasio ini pernah digunakan dalam penelitian yang dilakukan oleh Santosa dan Wedari (2007). Berikut ini rumus pertumbuhan laba:

$$
\text { Pertumbuhan laba }=\frac{\text { laba bersih }_{\mathrm{t}}-\text { laba bersih }_{\mathrm{t}-1}}{\text { laba bersih }_{\mathrm{t}-1}}
$$

\section{Opini Audit Tahun Sebelumnya (X5)}

Opini audit tahun sebelumnya didefinisikan sebagai opini audit yang diterima oleh perusahaan pada tahun sebelumnya. Variabel ini diukur dengan menggunakan variabel dummy, yaitu opini audit going concern diberi nilai 1, sedangkan opini audit non going concern diberi nilai 0. Pengukuran seperti ini pernah digunakan dalam penelitian Susanto (2009).

\section{Rasio Likuiditas (X6)}

Penelitian ini likuiditas diproksikan dengan rasio lancar. Rasio lancar untuk perusahaan yang normal berkisar pada angka 2. Rasio lancar yang rendah menunjukkan risiko likuiditas yang tinggi, sedangkan rasio lancar yang tinggi menunjukkan adanya kelebihan aktiva lancar, yang nantinya akan mempunyai pengaruh yang tidak baik terhadap profitabilitas perusahaan (Hanafi dan Halim, 2003: 79). Berikut ini rumus rasio lancar: 


$$
\text { Rasio lancar }=\frac{\text { aset lancar }}{\text { utang lancar }}
$$

\section{Rasio Aktivitas (X7)}

Rasio aktivitas menghitung efektivitas penggunaan total aktiva. Rasio yang tinggi biasanya menunjukkan menajemen yang baik. Sebaliknya, rasio yang rendah harus membuat manajemen mengevaluasi strategi, pemasaran, dan pengeluaran investasinya (Hanafi dan Halim, 2003: 83). Rasio aktivitas dalam penelitian ini diproksikan dengan perputaran total asset yang dirumuskan sebagai berikut:

$$
\text { Perputaran total aset }=\frac{\text { Penjualan }}{\text { total aset }}
$$

\section{Rasio Solvabilitas (X8)}

Rasio solvabilitas menghitung dana disediakan oleh kreditur. Rasio yang tinggi berarti perusahaan menggunakan financial leverage yang tinggi (Hanafi dan Halim, 2003: 84). Rasio solvabilitas dii berikut:

$$
\text { Total utang terhadap total aset }=\frac{\text { total utang }}{\text { total aset }}
$$

\section{Rasio Profitabilitas (X9)}

Rasio return on asset mengukur kemampuan perusahaan menghasilkan laba bersih berdasarkan tingkat aset tertentu. Rasio yang tinggi menunjukkan efesiensi manajemen aset, yang berarti efisiensi manajemen (Hanafi dan Halim, 2003: 86). Rasio profitabilitas dalam penelitian ini diproksikan dengan return on asset. Berikut ini rumus rasio return on asset:

$$
\text { return } \text { on asset }=\frac{\text { laba bersih }}{\text { total aset }}
$$

\section{ALAT ANALISIS DATA}

\section{Analisis Deskriptif}

Analisis deskriptif merupakan proses transformasi data penelitian dalam bentuk tabulasi sehingga mudah dipahami dan diinterpretasikan. Tabulasi 
menyajikan ringkasan penyusunan data dalam bentuk tabel numerik dan grafik. Ukuran yang digunakan dalam deskripsi antara lain berupa nilai rata-rata, deviasi standar, nilai minumum dan nilai maksimum (Indriantoro dan Supomo, 2011: 170). Statistik deskriptif dalam penelitian ini terdapat pemisahan kelompok, antara kelompok perusahaan yang menerima opini audit going concern, dan kelompok perusahaan yang menerima opini audit non going concern.

\section{Analisis Regresi Logistik}

Pengujian hipotesis menggunakan regresi logistik. Regresi logistik tidak perlu asumsi normalitas data pada variabel bebasnya (Ghozali, 2009: 333). Analisis regresi logistik digunakan karena pengukuran variabel dependen dalam penelitian ini menggunakan variabel dummy. Langkah-langkah melakukan analisis regresi logistik yaitu: (1) menilai model fit, (2) Cox dan Snell's $R$ Square atau R2, (3) menilai kelayakan model regresi, (4) matriks klasifikasi, (5) menguji koefisien regresi logistik.

\section{PEMBAHASAN}

\section{Deskripsi Objek Penelitian}

Metoda pemilihan sampel dalam penelitian ini dilakukan dengan menggunakan purposive sampling yaitu metoda pengambilan sampel berdasarkan kriteria-kriteria tertentu. Berdasarkan kriteria yang sudah ditetapkan diperoleh sebanyak 39 perusahaan yang dijadikan sampel dalam penelitian ini, disajikan sebagai berikut:

Tabel 1

Jumlah Sampel Penelitian

\begin{tabular}{|l|c|}
\hline Keterangan & Jumlah \\
\hline Perusahaan yang terdaftar di BEI 2008-2012 & 138 perusahaan \\
\hline $\begin{array}{l}\text { Perusahaan yang datanya tidak berhasil diperoleh } \\
\text { secara rutin 2008-2012 yang berupa } \text { annual report } \\
\text { dan laporan keuangan }\end{array}$ & \\
\hline Perusahaan yang datanya tidak bisa diolah & (97 perusahaan) \\
\hline Jumlah sampel penelitian & 39 perusahaan \\
\hline
\end{tabular}

Sumber: Data Sekunder, diolah (2013) 


\section{Menilai Model Fit}

\section{Tabel 2}

\section{Hasil Uji Model Fit}

\begin{tabular}{|c|l|r|}
\hline Step 1 & -2 Log likelihood akhir & 189,695 \\
\hline
\end{tabular}

Sumber: Data sekunder, diolah (2013)

Berdasar tabel 2 diketahui bahwa nilai -2 log likelihood akhir adalah sebesar 189,695 dan memiliki distribusi x2 dengan df 146 (156-10), dari tabel x2 dengan $\mathrm{df}=146$ didapat angka sebesar 175,198. Oleh karena nilai -2 log likelihood 189,695 lebih besar dari nilai x2 175,198 dengan alpha 5\% yang berarti hipotesis nol tidak dapat ditolak dan model fit dengan data.

\section{Cox dan Snell's R Square}

Pengujian Cox dan Snell's $R$ square yaitu untuk mengukur seberapa jauh kemampuan variabel-variabel independen dalam menjelaskan variasi variabel dependen. Berdasar tabel 3 nilai Cox dan Snell's $R$ Square sebesar 0,155 dan nilai Nagelkerke R2 sebesar 0,207 yang berarti variabilitas variabel dependen yang dapat dijelaskan oleh variabilitas variabel independen sebesar 20,7\%, sedangkan sisanya sebesar 79,3\% dijelaskan oleh variabel lain yang tidak dimasukan dalam penelitian.

\section{Tabel 3}

\section{Hasil Uji Cox and Snell's R Square}

\begin{tabular}{|c|c|}
\hline Cox \& Snell $\boldsymbol{R}$ Square & Nagelkerke $R$ Square \\
\hline 0,155 & 0,207 \\
\hline
\end{tabular}

Sumber: Data sekunder, diolah (2013)

\section{Menilai Kelayakan Model Regresi}

Pengujian Hosmer and Lemeshow's Goodness of fit test digunakan untuk menguji apakah data empiris sesuai dengan model (tidak ada perbedaan antara model dengan data sehingga model dapat dikatakan fit). Berdasarkan pada tabel 4 nilai probabilitas Hosmer and Lemeshow's Goodness of fit test sebesar 0,116>0,05 yang berarti model dapat memprediksi nilai observasinya atau dapat dikatakan model dapat diterima karena sesuai dengan data observasinya. 
Tabel 4

Hasil Uji Kelayakan Model Regresi

\begin{tabular}{|c|c|c|}
\hline Chi-square & Df & Signifikansi \\
\hline 12,881 & 8 & 0,116 \\
\hline
\end{tabular}

Sumber: Data sekunder, diolah (2013)

\section{Matriks Klasifikasi}

Berdasar tabel 5 menunjukkan kekuatan prediksi dari model regresi untuk memprediksi kemungkinan menerima opini audit going concern adalah 64\%. Hal ini mengindikasikan bahwa dengan model regresi yang digunakan, terdapat sebanyak 48 laporan keuangan yang diberi opini audit going concern dari total 75 laporan keuangan yang seharusnya diberi opini audit going concern. Kekuatan prediksi model perusahaan yang tidak menerima opini audit going concern adalah $71,6 \%$, hal ini menunjukkan bahwa model regresi yang digunakan adalah sebanyak 58 laporan keuangan yang tidak diberi opini audit going concern dari total 81 laporan keuangan yang seharusnya tidak diberi opini audit going concern, sedangkan tingkat ketepatan prediksi model secara keseluruhan adalah sebesar $67,9 \%$.

Tabel 5

Hasil Uji Matriks Klasifikasi

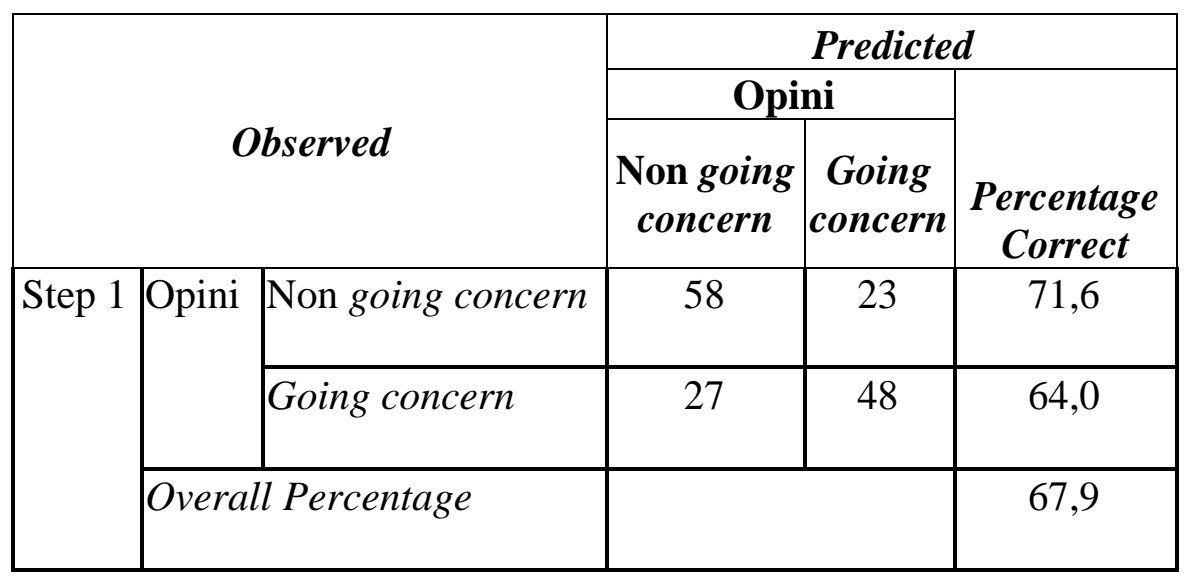

Sumber: Data sekunder, diolah (2013) 


\section{Menguji Koefisien Regresi}

Tabel 6

Hasil Pengujian variable in equation

\begin{tabular}{|l|c|c|l|}
\hline \multicolumn{1}{|c|}{ Variabel } & B & Sig & Keterangan \\
\hline Kualitas & $-0,351$ & 0,391 & H1 ditolak \\
\hline Tenure & 0,542 & 0,003 & H2 diterima \\
\hline Disclosure & $-1,885$ & 0,544 & H3 ditolak \\
\hline Pertumbuhan & 0,069 & 0,263 & H4 ditolak \\
\hline Opini Sebelumnya & 0,640 & 0,090 & H5 ditolak \\
\hline Likuiditas & $-0,048$ & 0,693 & H6 ditolak \\
\hline Aktivitas & 0,212 & 0,579 & H7 ditolak \\
\hline Solvabilitas & 1,251 & 0,308 & H8 ditolak \\
\hline Profitabilitas & $-1,276$ & 0,563 & H9 ditolak \\
\hline
\end{tabular}

Sumber: Data sekunder, diolah (2013)

Berdasar hasil output variable in equation pada tabel 6, variabel kualitas auditor yang diproksi menggunakan KAP big four dan KAP non big four tidak berpengaruh terhadap penerimaan opini audit going concern, artinya KAP big four maupun KAP non big four memiliki kesamaan objektivitas dalam memberikan opini audit going concern kepada auditee. Hal ini diperkuat dengan nilai rata-rata statistik deskriptif kelompok non going concern sebesar 0,62 , sedangkan nilai ratarata statistik deskriptif kelompok going concern sebesar 0,52 yang relatif tidak jauh berbeda. Hasil penelitian ini mendukung penelitian yang dilakukan oleh Susanto (2009) yang menyatakan kualitas auditor tidak berpengaruh.

Berdasar hasil output variable in equation pada tabel 6, variabel tenure yang diproksi menggunakan jumlah lamanya pemakaian KAP berpengaruh terhadap penerimaan opini audit going concern, artinya semakin lama perusahaan menggunakan KAP yang sama, maka semakin kecil kemungkinan perusahaan dalam menerima opini audit going concern. Hal ini sesuai dengan Dewayanto (2011) yang menyatakan bahwa perikatan audit yang lama akan menjadikan auditor kehilangan independensinya atas auditee. Dengan demikian, kemungkinan kecil auditee akan mendapatkan opini going concern. Hasil penelitian ini memperkuat hasil penelitian yang dilakukan oleh Junaidi dan Hartono (2010), serta Muttaqin (2012) yang menyatakan bahwa tenure berpengaruh terhadap penerimaan opini 
audit going concern.

Berdasar hasil output variable in equation pada tabel 6, variabel disclosure yang diproksi menggunakan indeks pengungkapan yang diwajibkan BAPEPAM tidak berpengaruh terhadap penerimaan opini audit going concern, artinya auditor dalam memberikan opini audit going concern kepada auditee tidak mempertimbangkan pengungkapan yang dipersyaratkan BAPEPAM. Hal ini diperkuat dengan nilai rata-rata hasil statistik deskriptif untuk kelompok non going concern sebesar 0,93 , sedangkan kelompok going concern nilai rata-ratanya sebesar 0,92 yang berarti semua perusahaan yang menerima opini non going concern ataupun menerima opini going concern, secara bersama-sama hampir memenuhi kewajiban pengungkapan yang dipersyaratkan BAPEPAM.

Berdasar hasil output variable in equation pada tabel 6, variabel pertumbuhan perusahaan yang diproksi menggunakan pertumbuhan laba tidak berpengaruh terhadap penerimaan opini audit going concern, artinya auditor dalam memberikan opini audit going concern kepada auditee tidak mempertimbangkan besar kecilnya laba yang diperoleh perusahaan. Hal ini diperkuat dengan nilai rata-rata statistik deskriptif kelompok perusahaan yang menerima opini audit going concern memiliki pertumbuhan laba sebesar 0,89 lebih besar dari nilai rata-rata kelompok opini audit non going concern sebesar 0,05.

Berdasar hasil output variable in equation pada tabel 6, variabel opini audit tahun sebelumnya tidak berpengaruh terhadap penerimaan opini audit going concern, artinya auditor dalam memberikan opini audit going concern kepada auditee tidak mempertimbangkan apakah opini audit tahun sebelumnya yang diterima oleh auditee. Akan tetapi, lebih cenderung mempertimbangkan kondisi yang sesungguhnya terjadi pada saat proses audit berlangsung. Hasil penelitian ini mendukung penelitian yang dilakukan oleh Prayitno (2010) yang menyatakan bahwa opini audit tahun sebelumnya tidak berpengaruh terhadap penerimaan opini audit going concern.

Berdasar hasil output variable in equation pada tabel 6, variabel rasio likuditas yang diproksi menggunakan rasio lancar tidak berpengaruh terhadap penerimaan opini audit going concern, artinya auditor dalam memberikan opini 
audit going concern kepada auditee tidak mempertimbangkan rasio likuiditas karena besar kecilnya rasio likuiditas bukan merupakan indikasi perusahaan mengalami kesulitan dalam mempertahankan kelangsungan hidupnya. Hal ini diperkuat dengan nilai rata-rata hasil statistik deskriptif kelompok non going concern sebesar 2,59, sedangkan kelompok going concern sebesar 2,02 yang berarti perusahaan yang menerima opini audit going concern ataupun opini audit non going concern, secara bersama-sama memiliki rasio lancar yang baik dikarenakan nilai rasio lancar lebih dari 2. Hasil penelitian ini mendukung penelitian yang dilakukan oleh Susanto (2009) yang menyatakan bahwa rasio lancar tidak berpengaruh terhadap penerimaan opini audit going concern.

Berdasar hasil output variable in equation pada tabel 6, variabel rasio aktivitas yang diproksikan total asset turnover tidak berpengaruh terhadap penerimaan opini audit going concern, artinya auditor dalam memberikan opini audit going concern kepada auditee tidak mempertimbangkan rasio aktivitas karena efektif atau tidaknya perusahaan dalam mengelola aset bukan merupakan indikasi perusahaan mengalami kesulitan dalam mempertahankan kelangsungan hidupnya. Hal ini diperkuat dengan nilai rata-rata statistik deskriptif kelompok non going concern sebesar 1,21, sedangkan kelompok going concern sebesar sebesar 1,25. Hal ini berarti perusahaan yang menerima opini audit going concern ataupun opini audit non going concern, secara bersama-sama memiliki kefektivan dalam mengelola aset perusahaan. Hasil penelitian ini memperkuat hasil penelitian Muttaqin (2012) yang menyatakan bahwa total asset turnover tidak berpengaruh terhadap penerimaan opini audit going concern.

Berdasar hasil output variable in equation pada tabel 6, variabel rasio solvabilitas yang diproksi menggunakan debt to total asset tidak berpengaruh terhadap penerimaan opini audit going concern, artinya auditor dalam memberikan opini audit going concern kepada auditee tidak mempertimbangkan rasio solvabilitas, karena besar kecilnya rasio sovabilitas bukan merupakan indikasi perusahaan mengalami kesulitan dalam mempertahankan kelangsungan hidupnya. Hal ini diperkuat dengan nilai rata-rata statistik deskriptif kelompok non going concern sebesar 0,42 , sedangkan nilai rata-rata kelompok going concern sebesar 
0,50. Hal ini berarti perusahaan yang menerima opini audit going concern ataupun opini audit non going concern, secara bersama-sama memiliki rasio solvabilitas yang baik dikarenakan nilai rasio solvabilitas yang rendah. Hasil penelitian ini tidak mendukung penelitian yang dilakukan oleh Susanto (2009) yang menyatakan bahwa debt to total asset berpengaruh terhadap penerimaan opini audit going concern.

Berdasar hasil output variable in equation pada tabel 6, variabel rasio profitabilitas yang diproksikan return on asset tidak berpengaruh terhadap penerimaan opini audit going concern, artinya auditor dalam memberikan opini audit going concern kepada auditee tidak mempertimbangkan rasio profitabilitas, karena besar kecilnya rasio profitabilitas bukan merupakan indikasi perusahaan mengalami kesulitan dalam mempertahankan kelangsungan hidupnya. Hal ini diperkuat dengan nilai rata-rata statistik deskriptif kelompok non going concern sebesar 0,12 , sedangkan nilai rata-rata statistik deskriptif kelompok going concern sebesar 0,10 . Hal ini berarti perusahaan yang menerima opini audit going concern ataupun opini audit non going concern, secara bersama-sama memiliki rasio profitabilitas yang relatif buruk, ini disebabkan karena nilai rata-rata yang relatif rendah.

\section{SIMPULAN, KETERBATASAN, DAN SARAN}

Berdasarkan analisis dan pembahasan hasil penelitian yang telah dipaparkan pada bab sebelumnya, sehingga dapat disimpulkan bahwa variable tenure berpengaruh terhadap penerimaan opini audit going concern. Sementara itu, kualitas auditor tidak berpengaruh terhadap penerimaan opini audit going concern. disclosure, pertumbuhan perusahaan, opini audit tahun sebelumnya, rasio likuiditas, rasio aktivitas, rasio solvabilitas, dan rasio profitabilitas tidak berpengaruh terhadap penerimaan opini audit going concern.

Adapun keterbatasan dalam melakukan penelitian ini, yaitu variabel penelitian ini menggunakan rasio likuiditas yang diproksi hanya menggunakan rasio lancar, rasio aktivitas diproksi total asset turnover, rasio solvabilitas diproksikan debt to total asset dan rasio profitabilitas diproksikan return on asset, 
sehingga tidak dapat menilai kinerja keuangan perusahaan secara komprehensif. Selain itu, variabel independen dalam penelitian ini hanya mampu menjelaskan variabel dependen sebesar 20,7\%. Sedangkan sisanya 79,3\% dijelaskan oleh faktorfaktor lain yang tidak dimasukkan ke dalam model penelitian.

Sehubungan dengan adanya keterbatasan dalam penelitian ini, sehingga diharapkan untuk penelitian selanjutnya disaran untuk menambahakan rasio keuangan guna menilai kinerja keuangan perusahaan secara komprehensif. Penelitian selanjutnya juga sebaiknya menambahkan variabel independen lain guna mempertinggi nilai Nagelkerke $R^{2}$, sehingga variabel independen lebih dapat menjelaskan variabel dependen.

\section{DAFTAR PUSTAKA}

Anthony, Robert. N dan Vijay Govindarajan. 2009. Sistem Pengendalian Manajemen. Edisi 11. Buku 2. Jakarta: Salemba Empat.

BAPEPAM-LK. 2006. Keputusan Nomor: KEP-134 /BL/2006: Kewajiban Penyampaian Laporan Tahunan bagi Emiten atau Perusahaan Publik [Online]. Didapatkan: < http:// www.bapepam.go.id [24>September 2013].

BAPEPAM-LK. 2008. Keputusan Nomor: KEP- /BL/2008: Independensi Akuntan yang Memberikan Jasa Audit di Pasar Modal [Online]. Didapatkan: < http:// www.bapepam.go.id [05>Oktober 2013].

Boynton, William C., Raymond N. Johnson, Walter G. Kell. 2003. Modern Auditing. Edisi 7. Jilid 2. Jakarta: Erlangga.

Dewayanto, Totok. 2011. “Analisis Faktor-faktor yang Mempengaruhi Penerimaan Opini Audit Going Concern pada Perusahaan Manufaktur yang Terdaftar di Bursa Efek Indonesia”. Fokus Ekonomi, Vol. 6, No. 1 Juni 2011: 81-104.

Financial Accounting Standard Board. 2008. Elements of Financial Statements, SFAC No. 6.

Financial Reporting and Qualitative Characteristics of Useful Financial Information, SFAC No. 8. 
Ghozali, Imam. 2009. Analisis Multivariate Lanjutan dengan Program SPSS. Semarang: Badan Penerbit Universitas Diponegoro.

Hanafi, M. Mamduh dan Abdul Halim. 2003. Analisis Laporan Keuangan. Yogyakarta: UPP AMP-YKPN.

Harahap, Sofyan Syafri. 2007. Teori Akuntansi. Edisi Ketiga. Jakarta: PT Raja Grafindo Persada.

Hendriksen, Eldon S. dan Michael F van Breda. 1992. Accounting Theory. Fifth Edition. Boston: Richard D. Irwin, Inc.

Ikatan Akuntansi Indonesia. 2001. Standar Profesional Akuntan Publik. Jakarta: Salemba Empat. 2007. Standar Akuntansi Keuangan. Jakarta: Salemba Empat.

Indriantoro, Nur dan Bambang Supomo. 2011. Metodologi Penelitian Bisnis untuk Akuntansi dan Manajemen. Yogyakarta: BPFE UGM

Institut Akuntan Publik Indonesia. 2011. Undang-Undang Republik Indonesia Nomor 5 Tahun 2011 tentang Akuntan Publik. Jakarta: Salemba Empat

Januarti, Indira dan Ella Fitrianasari. 2008. "Analisis Rasio Keuangan dan Rasio Non Keuangan yang Mempengaruhi Auditor dalam Memberikan Opini Audit Going Concern pada Auditee". Jurnal MAKSI Vol.8 Januari 43-58.

Junaidi dan Jogiyanto Hartono. 2010. "Faktor Non Keuangan pada Opini Going Concern”. Simposium Nasional Akuntansi Purwokerto.

Kieso, Donald E., Jerry J. Weygandt, Terry D. Warfield. 2002. Akuntansi Intermediate. Edisi Kesepuluh. Jilid 1. Jakarta: Erlangga.

Muttaqin, Ariffandita Nuri. 2012. Analisis Pengaruh Rasio Keuangan dan Faktor Non Keuangan terhadap Penerimaan Opini Audit Going Concern. Skripsi. Semarang. Universitas Diponegoro.

Noverio, Rezkhi. 2011. Analisis Pengaruh Kualitas Auditor, Likuiditas, dan Solvabilitas, terhadap Opini Audit Going Concern pada Perusahaan Manufaktur yang terdapat di Bursa Efek Indonesia. Skripsi. Semarang. 
Universitas Diponegoro.

Prayitno, Mokhamad Yogi. 2010. Analisis Faktor-faktor yang Dapat Mempengaruhi Auditor dalam Pemberian Opini Audit Going Concern. Skripsi. Yogyakarta. Universitas Pembangunan Nasional.

Ramadhany, Alexander. 2004. Analisis Faktor-faktor yang Mempengaruhi Penerimaan Opini Audit Going Concern pada Perusahaan Manufaktur yang Mengalami Financial Distress di Bursa Efek Jakarta. Tesis. Semarang. Universitas Diponegoro.

Santosa, Arga Fajar dan Linda Kusumaning Wedari. 2007. "Analisis Faktor yang Mempengaruhi Kecenderingan Penerimaan Opini Audit Going Concern”. JAAI, VOL.11, No.2, Desember 2007: 141-158.

Sari, Komala. 2012. Analisis Pengaruh Audit Tenure, Reputasi KAP, Disclosure, Ukuran Perusahaan dan Likuiditas terhadap Penerimaan Opini Audit Going Concern. Skripsi. Semarang. Universitas Diponegoro.

Susanto, Yulius Kurnia. 2009. "Faktor-faktor yang Mempengaruhi Penerimaan Audit Going Concern pada Perusahaan Publik Sektor Manufaktur” Jurnal Bisnis dan Akuntansi, Vol. 11, No. 3, Desember 2009: 155-173.

Suwardjono. 2005. Teori Akuntansi Perekayasaan Pelaporan Keuangan. Yogyakarta: BPFE Universitas Gajah Mada.

Widodo, Dian Mustika Sari. 2012. Faktor-faktor yang Mempengaruhi Auditor dalam Memberikan Opini Going Concern. Skripsi. Semarang. Universitas Diponegoro. 